\title{
The Eskimo Songs of Northwestern Alaska
}

\author{
THOMAS F. JOHNSTON ${ }^{1}$
}

\begin{abstract}
The findings are presented of ethnomusicological research in several Eskimo communities of northwestern Alaska where traditional music is still popular. In some of these communities, particularly at Point Hope, musical ceremonialism is considerable. There are three main classes of songs in use: game songs, songs-withinstories and dance songs. Song styles and dance styles differ from those of the Eskimo communities of southwestern Alaska, reflecting not only the ceremonialism formerly associated with whaling in the north, but also language differences.
\end{abstract}

RESUME. Les chants esquimaux du nord de l'Alaska. On expose les résultats de recherches ethnomusicologiques dans plusieurs communautés esquimaudes du nordonest de l'Alaska chez lesquelles la musique traditionnelle est encore populaire. Dans certaines collectivités, en particulier à Point Hope, l'importance du cérémonial musical est considérable. Trois types principaux de chants sont utilisés: chants qui accompagnent les jeux, chants inclus dans les contes, chants dansés. Les styles des chants et les styles des danses diffèrent de ceux des communautés esquimaudes de l'Alaska du sud-ouest, reflétant non seulement le cérémonial autrefois associé à la pêche à la baleine dans le nord, mais encore les différences de langage.

Резюме. Песни аскимосов северо-западной Аляски.

В работе представлены ревультаты зтномузыковедческих исследовании, проведенных в раяличных зскимосских иоселениях северо-западной Аляски, где по-прежннему популярна традиционная муаыка. В некоторьх поселениях, например в Пойн-Хоупе, вначительное место занимает обрлдовая музыка. Выделяются три основные грутпы песен: песни, сотровождающие игры; песни, сопровожддающие рассказывание историй и песни, сопровождаюпие танцы. Стиль зтих песен, как и стиль тандев, отличается от стиля, характерного для зскимосских общин юго-западной Аляски, и отражвет не только существовавшие ранее на севере обряды, свяванные с охотой на китов, но и явыковые разлияия.

\section{INTRODUCTION}

Study of the sound and style of Eskimo music in northwestern Alaska provides comparative information with which to supplement existing ethnological knowledge of Eskimo social life, and often yields clues to aesthetic processes not normally brought to light by purely anthropological research. The singing, dancing, and drumming heard today closely resemble that described by the earliest explorers, the sound of the music being a particularly tenacious and conservative element. Such change as has occurred is mainly evident in the dance situation - the social aspect - which has become increasingly secularized. As in the past, Eskimo music in Alaska is closely related to other aspects of culture. Some of these relationships have remained static; others have changed. Eskimo dance movements, for instance, still reflect subsistence activities such as scanning, harpooning, hauling and cutting, but an Eskimo dance is performed today not for the purpose of placating capricious hunting spirits, but to demonstrate community solidarity, ethnicity, and a reawakening of cultural awareness in the face of the encroachment of white people.

${ }_{1}^{1}$ Music Department, University of Alaska, College, Alaska 99701, U.S.A. 
The Eskimo songs of northwestern Alaska fall into four broad categories: game songs (qitkutim atuutaa), songs-within-stories (unipkaaq atuutilik), dance songs (uamipiaq), and special ceremonial dance songs (angaiyutikun atuutit). The most obvious ways in which the Eskimo music of northwestern Alaska differs from that of southern Alaska are in: the beating of the frame-drum from below, rather than from above; the standing, rather than the kneeling, of the male dancers; the very small use of decorative dance fans (de rigueur in the south); and the considerable musical ceremonialism that still survives (which never developed as much in the south and southwest of Alaska, although it certainly existed there).

In the representation of Eskimo words here, the orthography followed is that currently in use at the Eskimo Language Workshop, University of Alaska, and employed throughout the Alaska rural education system, in bilingual programmes, and by local Eskimo newspapers.

\section{GAME SONGS}

In this category the songs are related in form to the games they accompany. They are generally of limited range and have words that are meaningless to the singers.

Short songs called ayahaaq accompany string figure games, which are played across a wide area of the circumpolar regions. They are reputed to teach obedience, and belief is still occasionally to be encountered in a String Figure Spirit who punishes those who overindulge in the pastime of string figure playing. The relationship between form and function is evident in one type of string figure game: a loop is anchored around a raised boot, and then twisted, first in one direction and then in another, while the person's forefinger remains inserted in the loop; there are two exactly-equal song strophes which, if correctly timed to the two-way twisting, aid the player in ensuring that the loop will revert suddenly to its original untwisted condition when the player (with a loud whoop) extracts his forefinger at the end of the performance. In the game songs of the St. Lawrence Island Eskimos, the loop is anchored around the back of the head, rather than around the foot.

The game song category also includes songs for hopping games such as mitquliksraq, in which opposing lines of boys and girls in alternation sing and hop a few steps toward each other. When the lines eventually meet, those in one line attempt to disconnect the linked arms of those in the other and so break through. The hopping is timed to the asymmetrical rhythm of the songwords.

Other game songs accompany chase games such as annami-annaluuraq, in which a circle of children taunt one of their number outside the circle, representing an old woman or witch, who then chases the taunters.

Pebble juggling games are accompanied by long songs called iglukisaak. They feature a fast bouncy $2 / 4$ in eighth notes (quavers), the first and third pulse in each measure being heavily accented. This fact was early noted by Murdoch (1892 p. 384), who, however, erred in referring to their "monotonous tune."

Jenness (1925 p. 9) noted north Alaskan game songs in 1918, mentioning "a chant for hide-and-seek, a gambling song, a chant to the aurora, and chants accompanying string figures." 


\section{SONGS-WITHIN-STORIES}

The importance of this category of songs and their function within folk-tales appears to have been overlooked by Colby in his compendium of Eskimo folk-tales (Colby 1973). The songs are generally short, of limited range and sometimes feature either a recitative or some form of distorted delivery, such as growling and squeaking. The rhythm is often complex and unexpected, and dramatic changes of tonal centre and/or tempo may occur.

The songs accompany a multitude of folk-tales concerned with ancient heroes or legendary figures, as well as with beached whales, ten-legged polar bears, humanized wolves and foxes, birds, and various other arctic fauna with which the Eskimo of northwestern Alaska is familiar. The animal or bird generally sings the song for some magic purpose. The singing of them confers a magical power on the singer which enables him or her to master a difficult, threatening situation. In the case of songs sung by wolves, these generally contain threats or references to aggression. It is possible that wolves in folk-tales reflect much of the interpersonal hostility which is forbidden in traditional Eskimo society.

\section{DANCE SONGS}

Dance songs, which are generally composed by men and sometimes by women, are best classified according to the dances they accompany, which are either the atuutipiaq type to which motions are improvised for particular occasions, or the sayuun type, which already possess a set of fixed, known motions created previously and associated permanently with the dance song. The permanently assigned motions are not necessarily devised by the song's composer or owner (who inherited it); they are often the creation of a male hunting partner or trading associate. Composers of sayuun dance songs are held in greater esteem than composers of the atuutipiaq type; some, however, work on both. Women sometimes compose sayuun dance songs and/or devise sayuun motions, particularly if they are fairly wealthy and respected women.

Both Spencer (1959 p. 191) and Milan (1964) have used the classificatory term sayuun, but neither has provided a full explanation of it. The term atuutipiaq does not appear to have been noted previously by any investigator. The Inupiat Eskimo Dictionary (Webster and Zibell 1970) fails to give the various musical classificatory terms and other dance and song terms.

\section{Dance songs with fixed motions (sayuun)}

This is the most important category of Eskimo songs from northwestern Alaska, for it contains all of the valued dance songs to which a set of fixed, known motions have been carefully put by either the song's owner or one of the latter's fictitious kin or social associates, such as a namesake or a dance partner.

Lengthy rehearsals are held, and the fixed motions are learned by rote. Motions may be modified at rehearsals and are in approximate unison. They are closely timed to specific drumbeats within the song. Their number is determined by the length of the song, their nature by the song word topic, the sex of the dancers, the social occasion for which the song was originally composed, and present use. 
The creation of a set of dance motions to go with a composer's sayuun dance song may be an honour bestowed by the composer, a tribute to the composer, a satirical comment on the relationship between the two men involved, or even the forfeit which has to be paid by the loser of a typical Eskimo contest or game. For instance, men whalers who spend several tedious days camped out on the sea ice awaiting a sighting, commonly engage in games of checkers, with such a choreographic task imposed as the penalty for losing. Sayuun dance songs are the most valued socially because of their interpersonal nature and permanence. Their use cements social alliances. However, they are not necessarily the most musically elaborate, for their rhythmic development, as well as melodic improvisation during use, are somewhat inhibited by the fixed nature of the movements. One of their many social functions is as a vehicle for the polished musical entertainment of important visitors from other communities - on the occasion of an intervillage "inviting-in", for example — preceding the free dancing in which both sides join. "Inviting-in" is the present-day term used by English-speaking Eskimo musicians. The teams make a special point of learning the sayuun songs and motions of their rivals, from immigrants to their home village or from cassette recordings and observation. Most teams are inclined to resent this musical borrowing, calling it songstealing, particularly when the song borrowers are paid money to perform regularly for tourists, and use the acquired repertory for this despised - by other Eskimos - purpose. Teams employed by the airlines on a regular basis exist at Anchorage, Nome, Kotzebue and Barrow (only one of the latter town's three teams is involved). Each consists of about thirty Eskimos, who perform on a shift basis, so that a minimum of twenty appear on stage at a given performance.

An important subdivision of the sayuun category is taliq, meaning seated women's arm dances - the term means "arm". These are often paddling songs. At Wainwright there is no taliq category, but there is use of a paddling song category, paagurraqtuq.

This seated women's dance style, but not the term taliq, has been reported by Spencer (1959 p. 355) and Lantis (1947 p. 41). The latter's description is of an "arm dance performed by a woman seated in the bow of a boat. Women were formerly expected to do a great deal of boat-paddling, and showed tremendous endurance at this task. It is likely that the Wainwright form of seated women's dancing, which features paddling songs only, is close to the original type, and that others using a greater variety of arm motions are a development of this style.

Taliq is reputed to have arrived in the northwest of Alaska from the Inupiaqspeaking Little Diomede Island, vie the mainland coastal village of Wales. According to legend, taliq flourishes in the north of Alaska because in former times the north supported only men, and the south possessed but a single married woman. A northerner attempted one day to steal the southern woman and, in the ensuing struggle, the northerner succeeded in taking possession of the top half. Each man replaced the missing portion in wood, which is why, according to southerners, the northern woman is now a "wooden" dancer as far as her legs are concerned. The legend reflects the intermittent, limited wars which formerly occurred and the ancient custom of wife-stealing, plus the folkloristic bloodthirtiness of a people constantly engaged in dismembering the carcasses of their catches. Furthermore, 


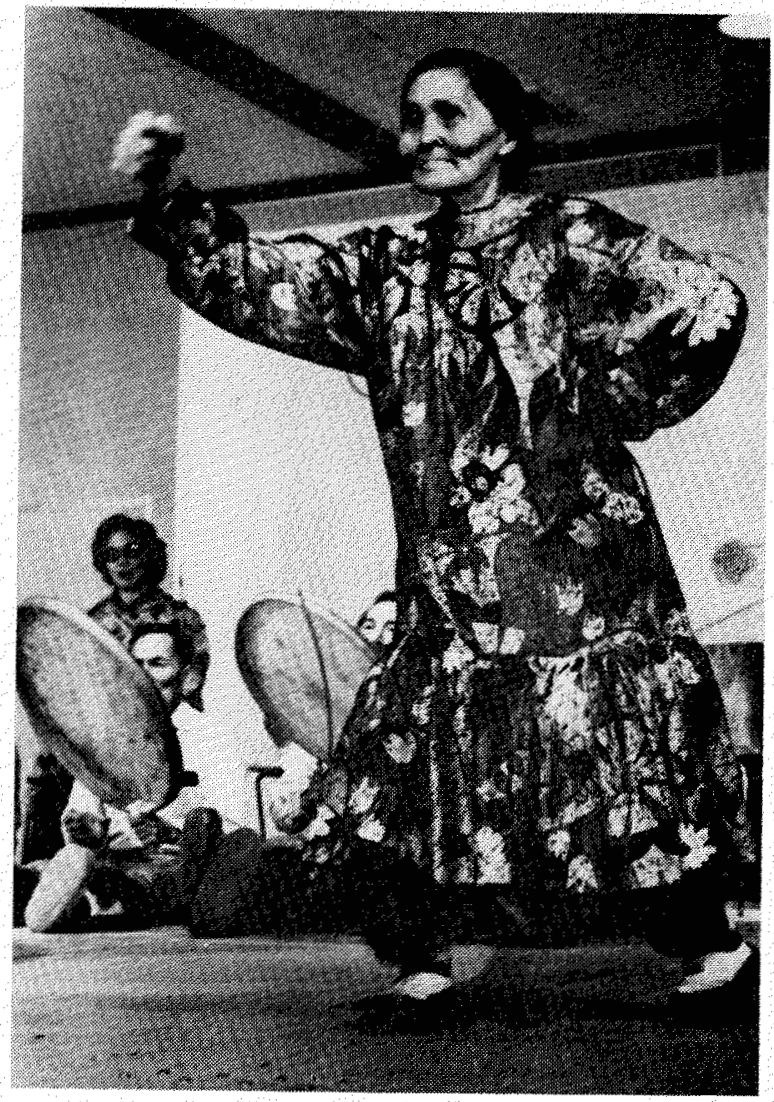

FIG. 1. The gestures of this woman dancer seem to reflect the value Eskimos place upon self-reliance, geniality and an expansive personality. The bright flowered parka, the sealskin boots and the dance mittens are de rigueur for these dances.

it reflects Eskimo carving skills, ancient musical rivalry, and the value placed upon graceful dancing, even with the feet immobile.

Taliq is at present being taught in several schools of northwestern Alaska by local musical exegetes who thereby keep the form alive.

\section{Dance songs with free motions (atuutipiaq)}

This category contains all of the dance songs which have no fixed choreography. Because of their social function the motions are free, and therefore no rehearsals are needed for their performance. The category is highly suitable for the final Invitation Dance of an "inviting in" when the guests are expected to step forward and join their hosts in a display of musical conviviality. Guests are usually unfamiliar with the sayuun dance motions of other villages, so the atuutipiaq dance songs provide a common musical meeting-ground. The Invitation Dance is their raison d'être.

At an "inviting in", individuals are expected to provide their own spontaneous dance motions to an atuutipiaq dance song (see Fig. 1). There are no rehearsals, and movements are not concerted, and so atuutipiaq performances become somewhat riotous and give rise to much individual competition and a degree of mirth.

In this class of dance song, the male dancers' feet must leave the ground, often both at once, unless too old or infirm. The boots are brought down in a series of 
jarring, flat-footed thuds, as though the purpose were to make as much noise as possible. It is here that the differences between the dance styles of the men and the women become most apparent.

Unlike in sayuun dances, where the motions of both men and women are in approximate unison, the women perform a rhythmic knee-bending, arm-curving dance and keep their eyes cast down to the floor, while the men stamp lustily all over the dance arena, legs rigid, in one of the few examples to be found among the Eskimos of extended floor-movement dance patterns. The stamping is known as kimmiatuq. Men seemingly attempt to puncture the floor with their heavy fur boots soled with the skin of the bearded seal, as they flex their biceps and shout gruffly in an almost frightening display of the type which led Beechey (1831 p. $395)$ to remark that the dancer "would have better become a pugilist." These movements may derive from past need to intimidate outsiders, by conveying to them the impression that local male athletic prowess was such that no surprise attack or other treachery would be worthwhile.

At Wainwright, atuutipiaq dance songs frequently feature use of vocables such as alala and ilili, vocables which are radically different to the standard $a-y a-y a n g a$ found across all of the north of Alaska. Use there of such unusual vocables was noted by Jenness (1922) who, however, incorrectly stated that they served as a stop-gap during memory lapses (they are, in fact, a guide to motion and melody).

In providing an outlet for improvisation in movement, atuutipiaq dancing fulfils a creative need not satisfied by sayuun. Atuutipiaq dance songs change over time more rapidly than do sayuun dance songs; word changes and modifications in the drum part also occur, primarily because such modifications do not interfere with any fixed set of motions. Atuutipiaq is thus a continuing medium for musical experimentation, and for musical interaction between song composers and their audiences.

Individual atuutipiaq dance songs possess a wider geographic distribution than do the sayuun, for they are learned and carried away by the visiting dance teams to a greater extent, and several are common throughout Eskimo Alaska, including those regions where the language is Yupik rather than Inupiaq. Atuutipiaq is performed by visitors. The style contains less use of eccentric drumming patterns which include unexpected rests accompanying meaningful choreography. While some examples are ancient, most are topical and make satirical reference to current events or local personalities. Like songs in the repertories of many societies, they are composed, enter the repertory, and shortly afterwards are either forgotten or semi-permanently established in most people's musical memory.

\section{SPECIAL CEREMONIAL DANCE SONGS}

There are six songs in this category (angaiyutikun atuutit), some of which are regarded as very secret. They are: the whalers' spinning-top dance song (kiapsaq); the puppet ceremony dance song (tohoyaqhuuqaun); the whalers' skin-toss dance songs (nalukataun) - these are not particularly secret; the whalers' masquerade dance songs (uingarung); the Northern Lights dance songs (kigugiyataun); and the box-drum dance songs (kalukhaq). 
The secrecy of these ceremonial dance songs stems from their shamanistic origins. They set the scene for the trances that were a bizarre demonstration of witchcraft (angaiyutikun atuutit means "songs of group of things done in a trance").

\section{Whalers' spinning-top dance song (kiapsaq)}

These are four in number, and are performed every New Year's Eve at Point Hope. The coiled string is pulled by a kneeling singer, who spins the top to the accompaniment of song, and releases the white feathers loosely inserted into holes in the upper part of the spinning-top. The whaler catching the whitest feather usually that of the snowy owl - is "guaranteed" the greatest success in the forthcoming whaling season. Failure to spin the top properly on the first try is an ill omen. The spinning-top dance songs, which today belong to whalers of the ungasiksikkaaq ceremonial lodge, were performed when the qagmaqtuuk lodge members were invited in during autumnal ceremonies. Although both lodges are still in existence, these dances are now performed mainly at the New Year's Eve dance and the June Whaling Feast.

A drawing of the type of spinning top still in use is given by Murdoch (1892 p. 377), while both Weyer (1932 p. 347) and Lantis (1947 p. 66) cite Rasmussen (1927 pp. 332-3) in a description of the top's musical and ceremonial use. Both VanStone (1962 p. 120) and Johnston (1975) were able to verify its continued musical use and the latter was able to collect a specimen top.

\section{Puppet ceremony dance song (tohoyaqhuuqaun)}

This dance song is associated today with the spinning-top musical ritual, and remains much as reported by Rasmussen (1927). The puppet is seated near the spinning top and made to move. In the case of a puppet collected by Nelson (1899 p. 334) at Point Hope (and all other known ceremonial puppets), the head can be turned with strings. Point Hope ceremonial puppets are still made by an Eskimo who was taught in the nineteen thirties by the late musical exegete, Sammaruuna. An example is in the University of Alaska Museum.

\section{Whalers' skin-toss dance (nalukataun)}

These dances, which are performed in June over most of the northwest of Alaska at the Whaling Feast, are called kakummisaaq after the pieces of whale meat which are affixed to sticks for cooking and eating. The skin-toss is described by almost all of the nineteenth century writers, and by several recent observers (Van Valin 1941 pp. 86-87), Milan (1964). VanStone (1962 p. 57) also gives a photograph.

In the skin-toss, thirty or more people stretch and bounce a large reinforced skin some 15 to 20 feet in diameter, sending skilled jumpers 20 to 30 feet into the air, often to the accompaniment of special songs. The tossed person must pass an inflated sealskin poke over his head and under his feet twice, without letting go of either end or losing his balance. The Alaska Council on the Arts produced a film Artist of the Arctic containing a skin-toss dance sequence filmed at Barrow.

For the skin-toss dance songs, whalers are expected to present new compositions marking, for example, their outstanding successes of the current whaling season. 
Whalers' masquerade dance songs (uingarung)

These accompany a New Year's Eve musical rite at Point Hope (Rainey 1947 p. 242; VanStone 1962 p. 121; Johnston 1973). Apparel of the opposite sex is donned and gifts pass between namesakes. Although the rite has most frequently been reported from the northwest of Alaska, it is known also in the southwest (Chanar 1973). It may have formerly had a broader distribution; for Nelson (1899 p. 367) reports musical transvestite masquerading for the St. Michael-Lower Yukon region. In the northwest, the masquerade ends the ceremonies of Christmas week, parallelling its former use as the final dance before the ceremonial house was closed for the second half of the winter.

\section{Northern Lights dance songs (kigugiyataun)}

These provide a means of intimidating women and children - an underlying aspect of many musical ceremonies (Lantis 1947). The Northern Lights (Aurora borealis) were once greatly feared, being thought to represent departed souls. One legend still tells of souls playing ball in the strangely lighted sky, and how, when the ball was lost, it was replaced by an Eskimo's head. Children are reported as having thrown dog's excrement at the Lights to keep them at bay.

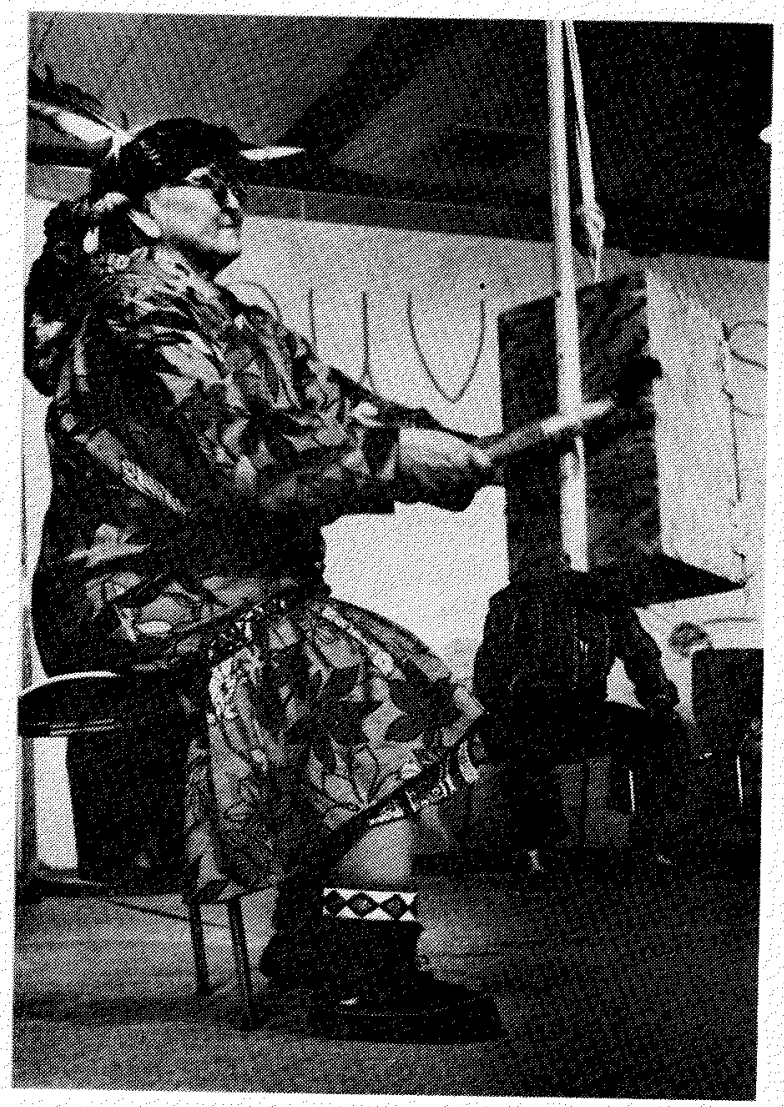

FIG. 2. The Wainwright box-drum is usually played by men, but women may sometimes beat it, as long as they don the loon-skin headdress. 


\section{Box-drum dance songs (kalukhaq)}

These dance songs are still performed, using the traditional large wooden boxdrum, at Wainwright and Barrow. The box-drum, whose beat is thought to be that of the eagle's heart, is mentioned by many writers (Murdoch 1892 p. 291; Curtis 1930 pp. 169-77; Van Valin 1941 p. 55; Spencer 1959 p. 223; Koranda 1972 p. 18; Binnington 1973 pp. 236-42; Johnson 1975). See Fig. 2.

The Wainwright box-drum is the smaller, being about 18 inches $(46 \mathrm{~cm})$ in height, while the Barrow version is about 36 inches high. The box-drum consists of a rectangular wooden case bearing wooden zigzag ornaments along the top, representing eagle feathers. It supports a vertical pole at one side, up and down which a club-like stick is beaten, sometimes in tremolo, sometimes in a solid, plodding 4/4 (crotchet) time. The pole is fixed to the box-drum with a strip of black baleen from the whale's mouth, and its uppermost end is decorated with a feather. A sound hole is cut in the bottom of the drum, and a handhold is supplied on the side opposite to the striking side. The whole is suspended from the roof by a rope. The beating is done spasmodically between bouts of gift-giving, during which the drummer, who is seated, stiffly reaches down and jerkily passes carvings and other gifts from the floor at his feet to a caller behind him. The caller takes the gift with a grotesque, exaggerated motion and calls the name of the recipient, who is generally one of the guests. This is part of a lengthy ritual carried out on social and ceremonial occasions at Wainwright and Barrow today, where the wearing of loonskin headdresses, the waving of feathered dance wands, and the use of entrance and exit songs, special choreography, and the unusual thudding sound of the box-drum distinguish the dance from regular sayuun and atuutipiaq dances.

At Wainwright today is to be found a box-drum procedure and series of dances almost exactly like that witnessed in 1913 by Van Valin (1941 pp. 55-56). It was learned from the Kotzebue community where it was formerly part of the Messenger Feast, and where it was photographed in ritual context during the late nineteenth century. The box-drum is suspended at one side of the dance arena, and beaten slowly and regularly by the seated drummer, who wears a loonskin headdress (tuutlik). At climactic points the regular rhythm is interrupted by a tremolo as the drumstick is struck, not against the protruding sounding board but against the vertical pole fixed to the side of the drum, which vibrates rapidly up and down its vertical length.

Three women carrying feathered dance wands stand behind three seated drummers holding the customary frame-drums, all six facing in the same direction. Facing them, with their backs to the audience, are three men standing with their hands upraised. Periodically during the dance the box-drummer bows forward, low down, and the standing men and women do likewise, lowering their heads and arms respectively to the ground, and the frame-drummers lower their drums. At times the frame-drums and the box-drum are played together.

In another interesting sequence, the rhythm of the box-drum accompanies the dancers advancing in a long file across the dance arena and back. The dancers, who wear loonskin headdresses, bend their knees, and keep their elbows pointed in front of their faces, as if to simulate a snout. (Fig. 3). This is one of the few 


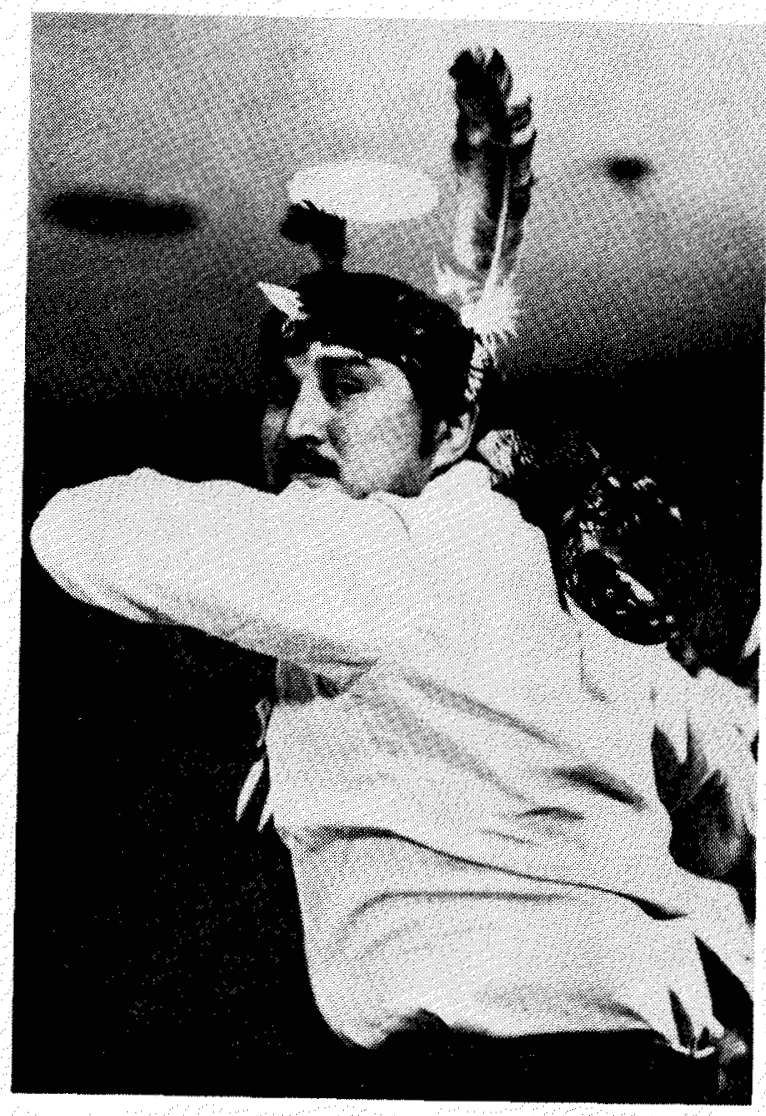

FIG. 3. In the box-drum dance, the leading dancer points his elbow like an animal's snout, and wears the loon-skin headdress, symbolic of the shaman's long dive to the ocean floor to communicate with the whaling spirits that dwell there.

Alaskan Eskimo dances in which women engage in an extended pattern of movements across a floor.

In another sequence, the box-drummer stands and swings his suspended drum out to one side and back. During this backing action, the dancers are required to anticipate correctly the side to which the box-drum will be swung, and to swing their two arms out to that side of the body. The drummer endeavours to deceive the dancers, making false passes to one side or the other, so that the action becomes a musical guessing game (Johnston 1975). It is reminiscent of the vagaries of wind and ocean, and corresponding whalers' skills in coping with them. See Fig. 4.

In the final dance sequence, two frame-drummers stand beating raised framedrums, acting as an exit through which the long file of men and women dancers must slowly pass, one at a time, singing the Exit Song (anilanga). At Barrow, hat rattles were formerly part of such elaborate dance sequences, as were mittenrattles (Murdoch 1892 pp. 265, 366; Van Valin 1941 p. 55). Today, mitten-rattles are found in use only at Point Hope, where they are made from seal gut and gun shells, and called qilgigun. It should not be overlooked that the ordinary word for frame-drum, qilaun (which is also the Canadian and Greenlandic Eskimo term), is derived from a word meaning shaman's power.

The ceremonial loonskin headdresses commonly worn today in both the north 


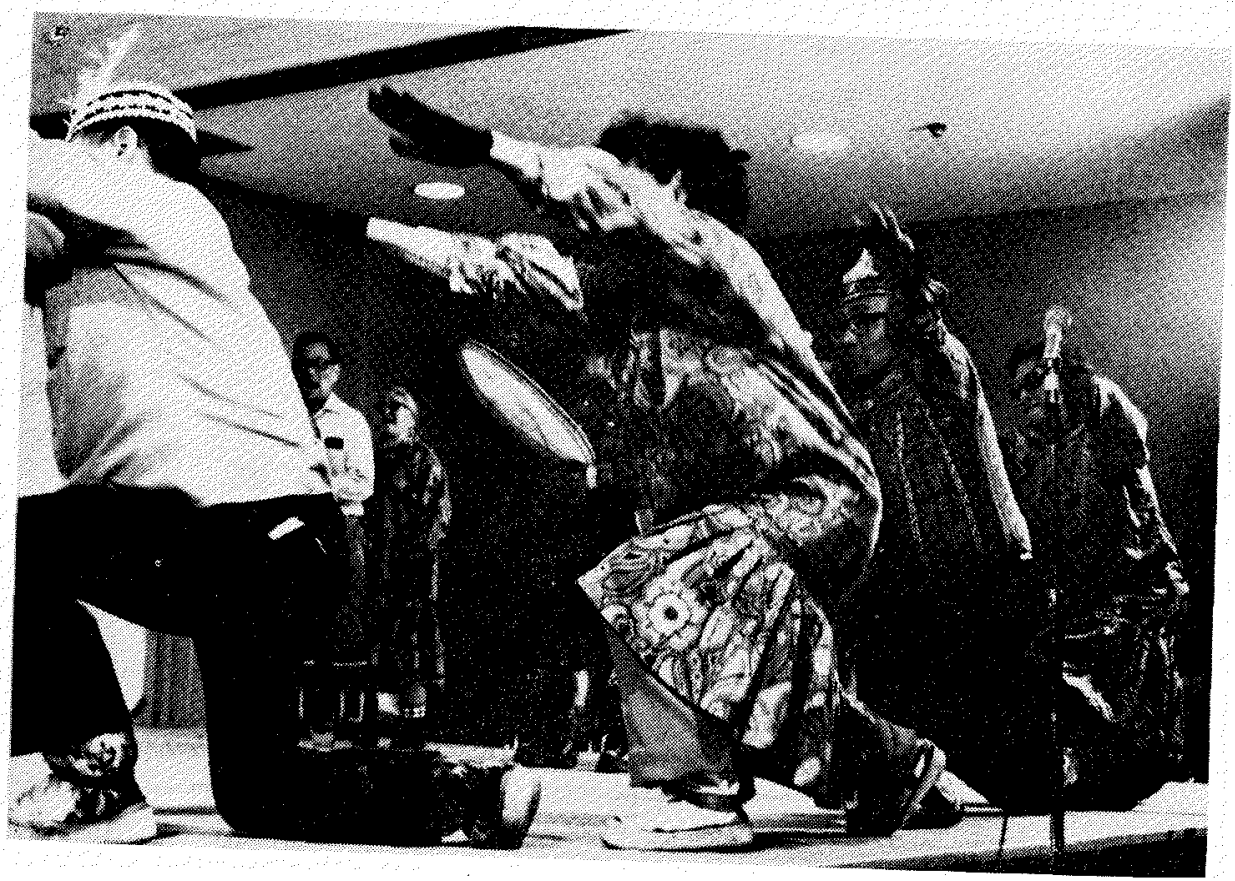

FIG. 4. The box-drum dance is one of the few dances which permits of extensive movements (in other dances the feet are usually immobile). The action during the swinging and beating of the box-drum is fast and vigorous.

and the south of Alaska, have been referred to by many writers, including Van Valin (1941 p. 54) and Spencer (1959 p. 225). The loon, a long-beaked bird, is found throughout the Arctic, particularly at Point Hope where it has long been a source of special interest. Its great diving powers are thought to aid the shaman in his long dive to the ocean floor to communicate with the whaling spirits. Of archaeological importance was the finding at Point Hope of a burial site in which had been interred a man and a loon, both fitted with permanent ivory eyes. This find may reflect the Eskimo legend of the blind man who asked a loon to restore his vision, which it does by repeatedly diving with the man into a lake. Common use of loonskin headdresses in Eskimo musical performances in Alaska is one more indication of the close link between music and ceremony there.

Masks are still carved today at Point Hope, but are no longer used as dance masks. Mask-like composite carvings are an important feature of ancient Point Hope burials, where they bear a striking resemblance to composite demon masks found in tombs at An-yang, the Shang dynasty capital in northern China. Several American and Russian anthropologists believe that Eskimo and Chinese cultures are historically linked (Larsen and Rainey 1949 pp. 120, 158; Collins 1971 pp. 271-8; Zhukovskaya 1973).

An interesting example of musical acculturation lies in the discovery of the bodies of two metal guitars on the tundra 50 miles $(80 \mathrm{~km})$ from Point Hope. These specimens are now in the museum of the Naval Arctic Research Laboratory at Barrow. The guitars were handmade by Eskimos from scrap metal sheeting, and fitted with unfretted wooden fingerboards. Thornton (1931 p. 78) 
observed such an instrument at Wales in 1890 . There may have been an aboriginal stringed instrument in the northwest. Jenness (1922) observed at Barrow a one-string tin-can lute with a peg, wooden bridge, and sinew. It was tapped with a wooden stick. The Eskimo player was from the interior of Alaska.

Before this paper is brought to a conclusion, brief reference must be made to the mobility of the performers and the diffusion of the songs. The whaling culture has given rise to considerable individual voyaging around the northwest coastline and out into the islands. Before the cold war set in, the range included Siberia. The learning of dance songs from other communities can even be seen as a motivation for mobility, for such learning is a constant source of boasting and pride. People from Point Hope enjoy relating how Little Diomede whalers in two skinboats brought their songs to Point Hope in 1963. One drummer at Point Hope relates how he went by trading ship to Herschel Island (off the northern coast of the Yukon Territory) in 1949, and there heard Point Hope songs being sung. They had been carried there from Barrow, where an individual from Point Hope had taken up residence. The divulgence of these songs was long a source of heated resentment at Point Hope. Diffusion of northwestern Eskimo songs started mainly in the last half of the nineteenth century, with the creation of Jabbertown, a polyglot whalers' post (which no longer exists) just outside Point Hope. The diffusion continues today, and in the 1974 Eskimo Northern Games at Inuvik, in the Northwest Territories, one of the most popular attractions was the Inupiaq-speaking Eskimo dance team from Fairbanks, where migrants from the coastal villages have taken up residence in an urban ghetto called Eskimo Village.

\section{ACKNOWLEDGEMENT}

Support for the field work for this study was provided by the U.S. National Science Foundation.

\section{REFERENCES}

BEECHEY, F. W. 1831. Narrative of a Voyage to the Pacific and Beering's Strait. London: Colburn and Bentley.

BINNINGTON, D. 1973. The development of a curriculum based on an integration of ethnomusicology and the social sciences. (Unpublished Ph.D. thesis, University of California, Los Angeles).

CHANAR, M. 1973. Eskimo annual dancing. Theata, 1: 14-16.

ColbY, B. N. 1973. A partial grammar of Eskimo folktales. American Anthropologist, 75 (3): 645-62.

Collins, H. 1971. Composite masks: Chinese and Eskimo. Anthropologica, 11 (1-2): 271-8. CURTIS, E. S. 1930. The North American Indian, Vol. 20. New York: Johnson Reprint (1970). JENNESS, D. 1922. Eskimo music in northern Alaska. The Musical Quarterly, 8: 377-83. and ROBERTS, H. 1925. Songs of the Copper Eskimo: Report of the Canadian Arctic Expedition 1913-18, Volume 14. Ottawa: Queen's Printer.

Johnston, T. 1973. Field notes from Point Hope, Book 1. (Unpublished manuscript, University of Alaska). 
7 (4): $17-26$.

1974. A historical perspective on Alaskan Eskimo music. The Indian Historian,

1975. Songs and dances of the Alaskan Eskimo. Viltis Folklore, 33 (5): 6-18.

KORANDA, L. 1972. Alaskan Eskimo Songs and Stories (record and booklet). Seattle: University of Washington Press.

LANTIS, M. 1947. Alaskan Eskimo Ceremonialism. Seattle: University of Washington Press.

MILAN, F. 1964. The Acculturation of the Contemporary Eskimo of Wainwright, Alaska. Fairbanks: University of Alaska (Anthropological Papers, 2 (2)).

MURDOCH, J. 1892. Ethnological results of the Point Barrow Expedition. Ninth Annual Report, U.S. Bureau of Ethnology. Washington: U.S. Bureau of Ethnology.

NELsON, E. W. 1899. The Eskimo about Bering Strait. Eighteenth Annual Report, U.S. Bureau of Ethnology. Washington: U.S. Bureau of Ethnology.

RAINEY, F. 1947. The Whale Hunters of Tigara. New York: American Museum of Natural History (Anthropological Papers, vol. 61, pt. 2).

RASMUSSEN, K. 1927. Across Arctic America. London: Putnam.

SPENCER, R. 1959. The North Alaskan Eskimo. Washington, D.C.: U.S. Bureau of Ethnology (Bulletin 171).

THORNTON, H. 1931. Among the Eskimos of Wales, Alaska, 1890-93. Baltimore: John Hopkins Press.

VANSTONE, J. w. 1962. Point Hope: An Eskimo Village in Transition. Seattle: University of Washington Press.

van valin, w. 1941. Eskimoland Speaks. Caldwell, Ohio: Caxton.

WEBSTER, D. and zIBELL, W. Inupiaq Eskimo Dictionary. Fairbanks: 1970 Summer Institute of Linguistics.

WEYER, E. 1932. The Eskimos. New Haven: Yale University Press.

ZHUKovSKAYA, N. L. 1970. K voprosu o tipologicheski skhodnykh yavleniyakh $\mathrm{v}$ shamanstve i buddizme (On the problem of typologically similar phenomena in shamanism and Buddhism.) Sovetskaya etnografiya, 6: 36-46. 